\title{
Decreased Iron in Cancer Cells and Their Microenvironment Improves Cytolysis of Breast Cancer Cells by Natural Killer Cells
}

\author{
XIAN-PENG JIANG and ROBERT L. ELLIOTT
}

Sallie A. Burdine Breast Foundation, Baton Rouge, LA, U.S.A.

\begin{abstract}
The association of iron with anticancer immunity is unclear. In order to determine the role of iron in anticancer immunity, we manipulated intracellular iron levels of the human MCF-7 and MDA-MB-231 breast cancer cell lines, and measured cytolysis of breast cancer cells by the natural killer cell line NK-92MI, nitric oxide (NO) production, tumor necrosis factor alpha (TNF $\alpha)$ production and gene expression of ferritin heavy chain (FTH1). We found that NK-92MI increased synthesis and release of $N O$ and TNF $\alpha$ into the medium during co-culturing of NK-92MI cells with MCF-7 or MDA-MB-231 cells. Addition of iron inhibited the cytolysis of the breast cancer cell lines. The iron chelator deferoxamine (DFOM) increased NK-92MI cytolysis to MCF-7 or MDA-MB-231 cells. Iron reversed cytotoxicity to breast cancer cells induced by $N O$, released from $S$-nitroso- $N$-acetyl-penicillamine (NO donor). Real time quantitative polymerase chain reaction showed that iron upregulated the expression of FTH1 and iron chelator DFOM reduced FTHI expression of MCF-7 and MDA-MB-231 cells. In conclusion, increased iron in cancer cells and their microenvironment protects cancer cells from natural killer cell cytolysis by antagonizing NO- and TNF $\alpha$-associated cytotoxicity and by up-regulation of ferritin expression in breast cancer cells. Conversely, a decrease in iron concentration caused by DFOM improves natural killer cytolysis of tumor cells.
\end{abstract}

Iron is required for cell growth and proliferation, and changes in intracellular iron availability can have significant effects on cellular metabolism, cell-cycle regulation and cell division. Iron is a cofactor for several key enzymes in

Correspondence to: Xian-Peng Jiang, 730 Colonial Drive, Suite E, Baton Rouge, LA 70806, U.S.A. Tel: +1 2259308731, Fax: +1 2259308732, e-mail: jiang@eehbreastca.com

Key Words: Natural killer cells, breast cancer, iron, deferoxamin, nitric oxide, TNF $\alpha$. cellular respiration and metabolism, including enzymes of the citric acid cycle and ribonucleotide reductase. This latter enzyme catalyzes the reduction of ribonucleotides to deoxyribonucleotides, which is the rate-limiting step in DNA synthesis. Iron is also required for macromolecule biosynthesis, necessary for cell growth and division $(1,2)$. Neoplastic cells have an increased requirement for iron because of their rapid growth and proliferation. An increased requirement for DNA synthesis is accompanied by increased expression of the iron-dependent enzyme ribonucleotide reductase (RR) (3). This is achieved primarily through upregulation of transferrin receptors (TFRs). However, it has also been suggested that tumor cells may have alternate routes of iron uptake, and these routes may be critical in achieving increased intracellular iron levels under conditions in which TFRs are saturated (4). We previously reported that the MCF-7 human breast cancer cell line up-regulates the expression of iron importer genes including TFRs and solute carrier family 11, member 2 (SLC11A2) and down-regulates the expression of iron exporter SLC40A1 (ferroportin) (5). Free iron $(\mathrm{Fe} 3+)$ is potentially hazardous to cells and has to be kept at very low concentrations. The protein ferritin has a high binding capacity for iron and protects cells from toxicity from free iron. Ferritin consists of two different subunits, known as heavy $(\mathrm{H})$ and light $(\mathrm{L})$ chains. H-Rich ferritin takes up iron faster than L-rich ferritin (6).

Iron deficiency has multiple effects on cell functions. Iron plays many critical roles in cancer progression through the cell cycle, and its deficiency can inhibit cell proliferation (7). Iron deficiency can significantly affect cellular metabolism by altering the expression and function of proteins that are central to the regulation of cellular metabolism and cellular respiration $(8,9)$. Therefore, the iron depletion induced by iron chelators is a potential method of cancer therapy $(7,10-13)$.

Both iron deficiency and iron excess can influence the functioning of the innate and adaptive arms of the immune system (14). Iron deficiency has been reported to be associated with increased susceptibility to infection in both experimental animals and humans, but the conflicting results 
of these studies have made them hard to interpret. The conflicting results could be due to variations in baseline iron status, the severity of deficiency or possible co-existing nutritional problems (15). The situation is further complicated by the observation that iron supplementation in humans, particularly in the tropics, can increase the risk of infections such as malaria and tuberculosis (15-17). Iron overload caused by dietary excess, abnormal hemolysis or inherited disorders is also associated with greater susceptibility to infection (18-20). Studies of patients with hemochromatosis gene $(H F E)$-associated hemochromatosis demonstrated a decrease in circulating lymphocytes, with $\mathrm{CD}^{+}$cells being particularly affected $(21,22)$, but these abnormalities have not been consistently observed. Experimental iron overload in rodents is not associated with changes in lymphocyte numbers, but has been suggested to affect proliferative and cytokine responses $(23,24)$. It has been shown that the iron-storing protein ferritin $\mathrm{H}$-chain can inhibit tumor necrosis factor alpha ( $\mathrm{TNF} \alpha)$-induced apoptosis by suppressing reactive oxygen species (25).

The association of iron in cancer cells and their microenvironment with host immunity is not clear. In the present study, we manipulated the level of iron in human breast cancer cell lines and their culture medium by iron supplementation or iron chelation. We also examined the cytolytic activity of the NK-92MI natural killer cell line against breast cancer cells.

\section{Materials and Methods}

Cell culture. The human breast cancer cell lines MCF-7 estrogen receptor-positive) and MDA-MB-231 (estrogen receptor-negative), and human NK-92MI natural killer cells were obtained from the American Type Culture Collection (Rockville, MD, USA). The MCF-7 and MDA-MB-231 cells were grown in alpha-minimum essential medium ( $\alpha$-MEM) supplemented with $10 \%$ fetal calf serum, $1 \mathrm{mM}$ glutamine and $0.05 \mathrm{mg} / \mathrm{ml}$ gentamicin (Invitrogen, Carlsbad, CA, USA). NK92MI is an interleukin-2 (IL2) independent natural killer cell line derived from the NK-92 cell line by transfection with human $I L 2$ cDNA. The cell line is cytotoxic against a wide range of malignant cells (26). NK-92MI cells were grown in $\alpha$-MEM without ribonucleosides and deoxyribonucleosides and with $2 \mathrm{mM}$ L-glutamine, $1.5 \mathrm{~g} / \mathrm{l}$ sodium bicarbonate, $0.2 \mathrm{mM}$ inositol, $0.02 \mathrm{mM}$ folic acid (Sigma Aldrich, St. Louis, MO, USA), $0.1 \mathrm{mM}$ 2-mercaptoethanol, $12.5 \%$ horse serum, $12.5 \%$ fetal bovine serum and $0.05 \mathrm{mg} / \mathrm{ml}$ gentamicin (Invitrogen). All cell lines were incubated in $5 \% \mathrm{CO}_{2}$ at $37^{\circ} \mathrm{C}$. Breast cancer cells were detached from tissue culture flasks by digestion with $0.05 \%$ trypsin and $0.53 \mathrm{mM}$ EDTA.

Measurement of cell growth by colorimetric method. The MTT colorimetric method is based on the capacity of mitochondrial enzymes of viable cells to reduce the yellow soluble salt 3-[4,5dimethylthiazol-2-yl]-2,5-diphenyltetrazolium bromide (MTT) to a purple-blue insoluble formasane precipitate which is quantified spectrophotometrically after dissolving in an organic solvent. The amount of MTT-formazan production is directly proportionate to the number of viable cells. MCF-7 or MDA-MB-231 cells ( 20.000 cells $/ 100 \mu 1$ per well) were plated in 96-well tissue culture plates. After $24 \mathrm{~h}$ of culture, the medium was replaced with 100 $\mu l$ of media containing iron salt $\left(\mathrm{FeCl}_{3}\right)$ or iron chelator deferoxamine (DFOM). The plate was then incubated for $4 \mathrm{~h}$. In order to measure the effect of iron on the cytotoxicity of the nitric oxide (NO) donor, $S$-nitroso- $N$-acetyl-penicillamine (SNAP) was added to breast cancer cells, 4000 cells/well were incubated with SNAP and iron for $72 \mathrm{~h}$. The supernatant was then carefully removed and $100 \mu \mathrm{l}$ of culture medium and $10 \mu \mathrm{lof} 5 \mathrm{mg} / \mathrm{ml}$ of MTT solution was added to the wells. The plate was incubated for another 4 hours in $5 \% \mathrm{CO}_{2}$ at $37^{\circ} \mathrm{C}$. The medium was carefully removed then $150 \mu$ lof dimethyl sulfoxide (DMSO) was added to the wells. After $30 \mathrm{~min}$ the optical density (OD) was measured at a wavelength of $492 \mathrm{~nm}$. Cell proliferation was expressed as a percentage that of the untreated control. All the experiments were carried out in triplicate wells and repeated three times independently.

Determination of cytolytic activity of human NK-92M natural killer cells. The MTT colorimetric method was adapted for evaluating the cytolytic activity of human NK-92MI cells towards breast cancer cells in vitro (27). We found that $100 \%$ of viable MCF-7 and MDA-MB-231 cells were able to attach to the wells of culture plates, but nonviable cells and cytolytic cells and NK92MI cells floated in the medium after $4 \mathrm{~h}$ of incubation. NK cells, and dead and cytolytic breast cancer cells can therefore be removed by aspiration. Thus, we simplified the MTT colorimetric method for detection of cytolytic function of NK-92MI cells against breast cancer cells. First, 10,000 MCF-7 or MDA-MB-231 cells in $100 \mu \mathrm{l}$ of medium were added to each well of a 96-well cell culture plate. NK-92MI (effector) cells were then added to the breast cancer target cells at effector/target cell ratios of 2.5:1, 10:1, and 40:1. Controls contained either breast cancer cells or NK$92 \mathrm{MI}$ cells alone. The final volume was $200 \mu \mathrm{l}$. Each plate was then incubated for 4 hours in $5 \% \mathrm{CO}_{2}$ at $37^{\circ} \mathrm{C}$. The medium from each well was carefully collected. NO and TNF $\alpha$ concentration was measured in the supernatant. Then, $100 \mu \mathrm{l}$ of complete $\alpha \mathrm{MEM}$ and $10 \mu \mathrm{l}$ of $5 \mathrm{mg} / \mathrm{ml}$ of MTT solution were added to each well. The plate was incubated for another 4 hours in $5 \% \mathrm{CO}_{2}$ at $37^{\circ} \mathrm{C}$. The media were aspirated and $150 \mu$ l of DMSO was added to each well. The OD was measured at a wavelength of $492 \mathrm{~nm}$. The percentage cytolysis by NK cells was calculated as follows: cytolysis $(\%)=[\mathrm{OD}$ of the control of breast cancer cells - $(\mathrm{OD}$ of experimental wells with cancer cells and NK-92MI cells - OD of the control of NK-92MI cells) $] \div$ (OD of the control of breast cancer cells $) \times 100$. Each experiment was repeated three times and average cytolysis was calculated.

Effect of iron and DFOM on cytolysis of breast cancer cells by NK92MI cells. Effector NK-92MI cells were co-cultured with breast cancer target cells at effector/target cell ratios of 2.5:1, 10:1 and $40: 1$. FeCl3 $(400 \mu \mathrm{M})$ or DFOM $(40 \mu \mathrm{M})$ was added to the mixture of NK-92MI and MCF-7 or MDA-MB-231 cells. Cells were incubated for $4 \mathrm{~h}$ in $5 \% \mathrm{CO}_{2}$ at $37^{\circ} \mathrm{C}$. NK-92MI cytolysis of breast cancer cells was measured using the MTT colorimetric method. The media from wells of co-culturing NK-92MI and breast cancer cells were collected for measurement of NO and TNF $\alpha$ concentration. All experiments were repeated three times and the average cytolysis was calculated. 
Measurement of NO in medium by the Griess Reagent System. Nitric oxide production was determined by measuring the nitrite $\left(\mathrm{NO}_{2}^{-}\right)$ level, which is one of two primary, stable and nonvolatile breakdown products of NO, using the Griess Reagent System (Promega, Madison, WI, USA). Firstly, $50 \mu$ l of culture supernatant from controls and the co-cultured NK-92MI and breast cancer cells were added in duplicate to wells of a 96 -well plate. Then $50 \mu \mathrm{l}$ of sulfanilamide solution was dispensed to all experimental samples and wells containing the dilution series for the nitrite standard reference curve. The plate was incubated for 5-10 minutes at room temperature, protected from light. Finally, $50 \mu \mathrm{l}$ of $\mathrm{N}-1$ napthylethylenediamine dihydrochloride solution was dispensed into all wells. The plate was incubated for 5-10 $\mathrm{min}$ at room temperature, protected from light. A purple/magenta color forms and its absorbance was measured within 30 minutes in a plate reader (Thermo Labsystems Multiskan MS, ThermoFisher, Waltham, MA, USA) with a $540 \mathrm{~nm}$ filter. The concentration of each sample was determined by comparison to the nitrite standard reference curve.

Human TNF $\alpha$ immunoassay. Human TNF $\alpha$ concentration was measured with a Quantikine HS TNF $\alpha$ ELISA kit (R\&D Systems, Minneapolis, MN, USA). All reagents and standards were prepared as instructed. Fifty microliters of Assay Diluent RD1F was added to each well. Two hundred microliters of standards, supernatants of controls or the co-cultured NK-92MI and breast cancer cells were dispensed into duplicate wells. The plate was incubated for 3 hours at room temperature and washed six times. Two hundred microliters of Conjugate was added to each well. The plate was incubated for 2 hours at room temperature and washed 6 times. Fifty microliters of Substrate Solution was dispensed to each well and plates were incubated for 1 hour at room temperature, then $50 \mu \mathrm{l}$ Amplifier Solution was added to each well and plates further incubated for $30 \mathrm{~min}$ at room temperature. Finally, $50 \mu \mathrm{l}$ Stop Solution was added to each well and the OD of wells in plate was read at $492 \mathrm{~nm}$ within $30 \mathrm{~min}$ The concentration of each sample was determined by comparison to the TNF $\alpha$ standard reference curve.

Real-time quantitative polymerase chain reaction $(q P C R)$. We used real-time qPCR to determine the effect of iron $(\mathrm{FeCl} 3)$ and iron chelator on ferritin heavy chain (FTH1) mRNA expression. The human MCF-7 and MDA-MB-231 breast cancer cell lines were treated with $\mathrm{FeCl}_{3}$ or the iron chelator DFOM for 4 hours at $37^{\circ} \mathrm{C}$ and $5 \% \mathrm{CO}_{2}$. The cells were removed from plates by trypsin-EDTA digestion. Total RNA of breast cancer cells was isolated with the PurLinkTM RNA Kit (Invitrogen). cDNA was then synthesized with High Capacity RNA-to-cDNA kit (Applied Biosystems, Grand Island, NY, USA). In brief, $2 \mu \mathrm{g}$ of total RNA was mixed with $10 \mu \mathrm{l}$ of 2x RT buffer and $1 \mu \mathrm{l}$ of $20 \times$ Enzyme Mix and water to a total reaction volume of $20 \mu \mathrm{l}$. The reaction mixture was incubated for 60 minutes at $37^{\circ} \mathrm{C}$ and then for 5 minutes at $95^{\circ} \mathrm{C}$ to stop the reaction. The cDNA was ready for real-time PCR application or long-term storage in a freezer. FTH1 gene expression quantification was performed with TaqMan ${ }^{\circledR}$ Gene Expression Assays. The primers and probes (PrimeTime Mini qPCR assay) of FTHI and. $\beta$-actin (ACTB) genes were synthesized by Integrated DNA Technologies (IDT, Coralville, IA, USA). The sequences were as follows: FTH1: TACCTGAA TGAGCAGGTGAAAG (forward), GATATTCCGCC AAGCCAGAT (reverse), and AGAATTGGGTGACCACGTGA CCAA (probe); ACTB: AGAAAGGGTGTAACGCAACTAA (forward), GGATCA GCAAGCAGGAGTATG (reverse), and TCGTCCACCGCAAATG CTTCTAGG (probe). ACTB was used as internal gene control to normalize the PCRs for the amount of RNA added to the reverse transcription reactions. Then $40 \mu$ of real-time qPCR reaction mixture containing $20 \mu \mathrm{l}$ of TaqMan ${ }^{\circledR}$ universal PCR master mix (Applied Biosystems), $4 \mu \mathrm{l}$ of $10 \times$ PrimeTime Mini qPCR assay (IDT) and $16 \mu \mathrm{l}$ of cDNA (100 ng). The qPCR reaction was aliquoted in triplicate to wells of a 384-well PCR plate. The plate was sealed, briefly centrifuged, and reaction performed as using the $7900 \mathrm{HT}$ real-time PCR system (Applied Biosystems). The standard mode ran as $2 \mathrm{~min}$ at $50^{\circ} \mathrm{C}$ and $10 \mathrm{~min}$ at $95^{\circ} \mathrm{C}$, and 40 cycles $\left(15 \mathrm{sec}\right.$ at $95^{\circ} \mathrm{C}$ and 1 minute at $\left.60^{\circ} \mathrm{C}\right) . \mathrm{FTHl}$ gene expression was determined by relative quantification which related the signal of the target transcript in a treated group (iron- or DFOM-treated) to that of another sample such as an untreated control. We analyzed the relative quantification with RQ Manager 1.2 software (Applied Biosystems). The relative expression of the studied samples was assessed using comparative delta-delta CT method and is presented as relative quantity (RQ) value.

Statistical analysis. The data were analyzed with a paired $t$-test and are presented as mean \pm standard deviation (SD). Findings were considered significant at $p<0.05$.

\section{Results}

NK-92MI cytolysis of breast cancer cells is associated with the synthesis and release of NO and TNF $\alpha$. NK-92MI and MCF-7 or MDA-MB-231 cells were co-cultured for $4 \mathrm{~h}$ in $5 \% \mathrm{CO}_{2}$ at $37^{\circ} \mathrm{C}$ with $\mathrm{NK}-92 \mathrm{MI} /$ cancer cell ratios of $2.5: 1$, 10:1 and 40:1. We found only low levels of NO and TNF $\alpha$ in the media of cultured NK-92MI cells. NO and TNF $\alpha$ were undetectable in the media from cultures of MCF-7 and MDA-MB-231 cells. When NK-92MI and cancer cells were co-cultured, levels of $\mathrm{NO}$ and $\mathrm{TNF} \alpha$ were significantly increased (Table I). The addition of $\mathrm{FeCl}_{3}(400 \mu \mathrm{M})$ or DFOM $(40 \mu \mathrm{M})$ did not change the NO nor the TNF $\alpha$ level in the medium (Table II). These results suggest that cytolytic function of NK cells is associated with synthesis and release of nitric oxide and TNF $\alpha$.

Iron inhibits cytolysis of MCF-7 breast cancer cells by $\mathrm{NK}$ $92 \mathrm{MI}$ cells. In order to determine the effect of iron $\left(\mathrm{FeCl}_{3}\right)$ and iron chelator (DFOM) on cell cytolysis by NK killer, we first determined the appropriate concentration of iron or DFOM to be added to the culture media. $\mathrm{FeCl}_{3}$ concentrations higher than $500 \mu \mathrm{M}$ significantly change the $\mathrm{pH}$ of the medium (turns media yellow). A $\mathrm{FeCl}_{3}$ concentration of $400 \mu \mathrm{M}$ or less did not inhibit the growth of MCF-7 and MDA-MB-231 cells during 4 hours of incubation (all $p>0.05$ ). Thus we chose $400 \mu \mathrm{M}$ as the greatest concentration of iron to be used in culture. We cocultured $1 \times 10^{5}$ of NK-92MI and $1 \times 10^{4} \mathrm{MCF}-7$ or MDAMB-231 cells (10:1) in media containing $50 \mu \mathrm{M}, 200 \mu \mathrm{M}$ and $400 \mu \mathrm{M}$ of $\mathrm{FeCl}_{3}$. The control was a mixture of $1 \times 10^{5}$ of NK-92MI and $1 \times 10^{4}$ cancer cells without additional iron. 
Table I. Concentrations of nitrite and tumor necrosis factor alpha (TNF $\alpha$ ) in culture medium when NK-92MI cells were co-cultured with MCF-7 or $M D A-M B-231$ cells for $4 \mathrm{~h}$.

\begin{tabular}{|c|c|c|c|}
\hline Cell line & Number of cells (ratio) ${ }^{\mathrm{a}}$ & Nitrite $(\mu \mathrm{M})$ & $\mathrm{TNF} \alpha(\mathrm{pg} / \mathrm{ml})$ \\
\hline \multirow[t]{3}{*}{ NK-92MI } & $2.5 \times 10^{4}$ & $0.50 \pm 0.09$ & $0.24 \pm 0.12$ \\
\hline & $1 \times 10^{5}$ & $1.10 \pm 0.16$ & $0.52 \pm 0.22$ \\
\hline & $4 \times 10^{5}$ & $1.50 \pm 0.18$ & $1.36 \pm 0.45$ \\
\hline MCF-7 & $1 \times 10^{4}$ & Undetectable & Undetectable \\
\hline MDA-MB-231 & $1 \times 10^{4}$ & Undetectable & Undetectable \\
\hline \multirow[t]{3}{*}{ NK-92MI+MCF-7 } & $2.5 \times 10^{4}+1 \times 104(2.5: 1)$ & $1.20 \pm 0.26, p<0.05$ & $0.67 \pm 0.21, p<0.05$ \\
\hline & $1 \times 10^{5}+1 \times 10^{4}(10: 1)$ & $3.29 \pm 0.68, p<0.01$ & $1.31 \pm 0.43, p<0.05$ \\
\hline & $4 \times 10^{5}+1 \times 10^{4}(40: 1)$ & $4.30 \pm 0.75, p<0.01$ & $2.50 \pm 0.48, p<0.05$ \\
\hline \multirow[t]{3}{*}{ NK-92MI+MDA-MB-231 } & $2.5 \times 10^{4}+1 \times 1^{04}(2.5: 1)$ & $0.99 \pm 0.25, p<0.05$ & $0.61 \pm 0.18, p<0.05$ \\
\hline & $1 \times 10^{5}+1 \times 10^{4}(10: 1)$ & $2.89 \pm 0.96, p<0.05$ & $1.40 \pm 0.48, p<0.05$ \\
\hline & $4 \times 10^{5}+1 \times 10^{4}(40: 1)$ & $3.67 \pm 0.78, p<0.01$ & $2.67 \pm 0.61, p<0.05$ \\
\hline
\end{tabular}

aRatio of NK-92MI to MCF-7 or MDA-MB-231 cells. Data are the mean \pm standard deviation of three replicates. $p$-Values reported for comparison with NK-92MI cells by paired $t$-test.

Table II. Effect of iron $\left(\mathrm{FeCl}_{3}\right)$ and iron chelator deferoxamine (DFOM) on the level of nitric oxide and TNFa in culture medium when NK-92MI and breast cancer cells were co-cultured for $4 \mathrm{~h}$.

\begin{tabular}{|c|c|c|c|c|c|}
\hline \multirow[b]{2}{*}{ Cell line } & \multirow[b]{2}{*}{ Treatment } & & \multicolumn{3}{|c|}{ Ratio of NK-92MI to MCF-7 or MDA-MB-231 cells } \\
\hline & & & $2.5: 1$ & $10: 1$ & $40: 1$ \\
\hline \multirow[t]{6}{*}{$\mathrm{MCF}-7$} & Nitrite $(\mu \mathrm{M})$ & 0 (control) & $1.20 \pm 0.26$ & $3.29 \pm 0.68$ & $4.30 \pm 0.75$ \\
\hline & & $400 \mu \mathrm{M}$ iron & $1.97 \pm 0.40^{\mathrm{NS}}$ & $3.49 \pm 0.57 \mathrm{NS}$ & $3.89 \pm 0.12^{\mathrm{NS}}$ \\
\hline & & $40 \mu \mathrm{M}$ DFOM & $1.05 \pm 0.31^{\mathrm{NS}}$ & $2.73 \pm 0.58^{\mathrm{NS}}$ & $3.17 \pm 0.43^{\mathrm{NS}}$ \\
\hline & $\mathrm{TNF} \alpha(\mathrm{pg} / \mathrm{ml})$ & 0 (control) & $0.67 \pm 0.21$ & $1.31 \pm 0.43$ & $2.50 \pm 0.48$ \\
\hline & & $400 \mu \mathrm{M}$ iron & $0.83 \pm 0.34 \mathrm{NS}$ & $1.54 \pm 0.63^{\mathrm{NS}}$ & $2.63 \pm 0.63^{\mathrm{NS}}$ \\
\hline & & $40 \mu \mathrm{M}$ DFOM & $0.51 \pm 0.17^{\mathrm{NS}}$ & $1.21 \pm 0.32^{\mathrm{NS}}$ & $2.10 \pm 0.23^{\mathrm{NS}}$ \\
\hline \multirow[t]{6}{*}{ MDA-MB-231 } & Nitrite $(\mu \mathrm{M})$ & 0 (control) & $0.99 \pm 0.25$ & $2.89 \pm 0.96$ & $3.67 \pm 0.78$ \\
\hline & & $400 \mu \mathrm{M}$ iron & $1.23 \pm 0.46^{\mathrm{NS}}$ & $2.84 \pm 0.34 \mathrm{NS}$ & $2.99 \pm 0.27^{\mathrm{NS}}$ \\
\hline & & $40 \mu \mathrm{M}$ DFOM & $1.11 \pm 0.37 \mathrm{NS}$ & $3.12 \pm 0.65^{\mathrm{NS}}$ & $3.33 \pm 0.77^{\mathrm{NS}}$ \\
\hline & $\mathrm{TNF} \alpha(\mathrm{pg} / \mathrm{ml})$ & 0 (control) & $0.61 \pm 0.18$ & $1.40 \pm 0.48$ & $2.67 \pm 0.61$ \\
\hline & & $400 \mu \mathrm{M}$ iron & $0.55 \pm 0.11^{\mathrm{NS}}$ & $1.83 \pm 0.54 \mathrm{NS}$ & $2.50 \pm 0.51^{\mathrm{NS}}$ \\
\hline & & $40 \mu \mathrm{M}$ DFOM & $0.81 \pm 0.25^{\mathrm{NS}}$ & $1.27 \pm 0.34 \mathrm{NS}$ & $2.89 \pm 0.31^{\mathrm{NS}}$ \\
\hline
\end{tabular}

NS: Not significant, compared to the medium control, $p>0.05$ by paired $t$-test. Data are the mean \pm standard deviation of three replicates.

After 4 hours of incubation, we used an MTT assay to measure cytolysis of breast cancer cells by NK-92MI cells. Both $200 \mu \mathrm{M}$ and $400 \mu \mathrm{M}$ of $\mathrm{FeCl}_{3}$ significantly inhibited the cytolysis of cancer cells by NK-92MI cells (all $p<0.05$ ), but $50 \mu \mathrm{M}$ of $\mathrm{FeCl}_{3}$ did not $(p>0.05)$ (Table III).

The iron chelator DFOM increases NK-92MI cell cytolysis of breast cancer cells. DFOM concentration of $40 \mu \mathrm{M}$ or less did not suppresses the growth of MCF-7 or MDA-MB-231 cells $(p<0.05)$. Therefore we used $40 \mu \mathrm{M}$ as the highest concentration of DFOM in the medium. MTT assays showed that both $10 \mu \mathrm{M}$ and $40 \mu \mathrm{M}$ of DFOM significantly increased the cytolysis of cancer cells by NK-92MI cells, but $2.5 \mu \mathrm{M}$ of DFOM did not $(p>0.05)$ (Table III).
Iron neutralizes the cytotoxicity of NO to MCF-7 and MDA$M B-231$ cells. To determine the effect of $\mathrm{FeCl} 3$ on the cytolytic function of NO during co-culturing of NK-92MI and breast cancer cells, we exposed breast cancer cells to NO released the NO donor SNAP with/without iron for 72 hours in $5 \% \mathrm{CO}_{2}$ at $37^{\circ} \mathrm{C}$. MTT colorimetric assay showed SNAP alone inhibited the proliferation of breast cancer cells in a dosage-dependent manner. Addition of iron inhibited cytotoxicity of SNAP to MCF-7 cells (Figure 1). Iron similarly neutralized the cytotoxicity of SNAP to MDAMB-231. Thus, NO from NK-92MI cells may deplete intracellular iron of MCF-7 and MDA-MB-231 cells. Iron inhibited the cytolysis of breast cancer cells by NK-92MI cells by reversing the iron-depleting effect of nitric oxide. 


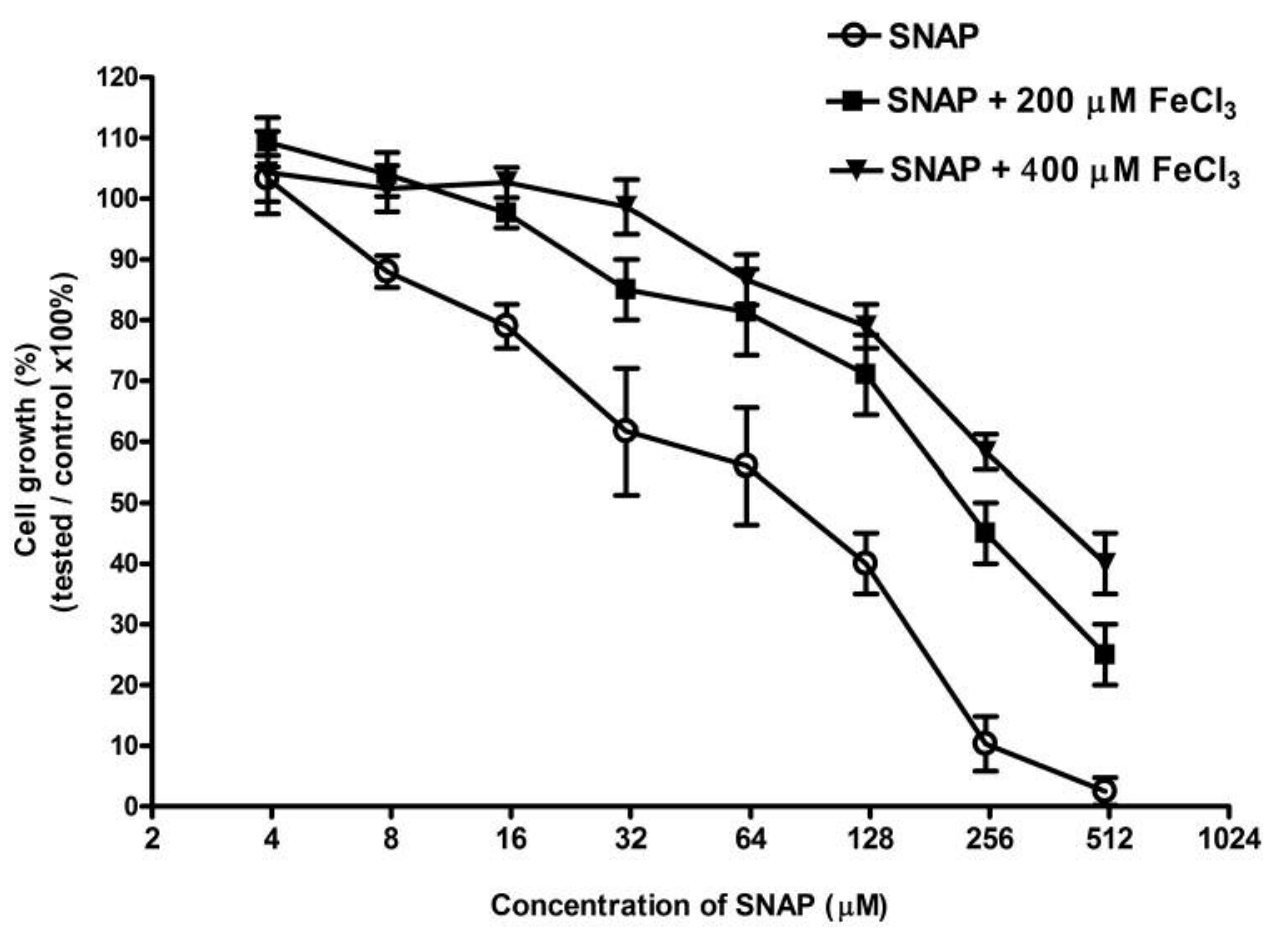

Figure 1. Iron inhibits the cytotoxicity of S-nitroso-N-acetyl-penicillamine (SNAP), a nitric oxide donor, to MCF-7 cells during 72 hours of incubation. Cell growth was determined by MTT assay.

Iron increases and DFOM reduces FHT1 mRNA expression in $M C F-7$ and $M D A-M B-231$. The relative expression of FHT1 was determined using the delta-delta CT method. Figure 2 shows that iron increases mRNA expression of FTH1 $\left(\log _{2} \mathrm{RQ}>0\right)$ in MCF-7 and MDA-MB-231 cells when treated with 50, 200 and $400 \mu \mathrm{M}$ of $\mathrm{FeCl} 3$ for 4 hours. On the other hand, the expression of FTH1 decreased $\left(\log _{2} \mathrm{RQ}<0\right)$ when breast cancer cells were incubated in media containing $2.5,10$ and $40 \mu \mathrm{M}$ of DFOM for 4 hours (Figures 2 and 3).

\section{Discussion}

Natural killer cells are large granular lymphocytes capable of destroying cells infected by virus or bacteria and susceptible tumor cells without prior sensitization and restriction by major histocompatibility complex antigens. Once the target is recognized by NK cells, their cytotoxic ability is mainly mediated via two main pathways. A membrane-disrupting protein, perforin, and a family of structurally related serine protease, granzyme, are secreted by exocytosis, which jointly induce apoptosis of the target cells. In the second pathway, caspase-dependent apoptosis takes place involving the association of death receptors (e.g. FAS/CD95) on target cells with their equivalent ligands such as FASL and tumor necrosis factor-related
Table III. Effects of iron $\left(\mathrm{FeCl}_{3}\right)$ and iron chelator deferoxamine (DFOM) on cytolysis of breast cancer cells by NK-92MI cells during 4 hours of incubation (details in the Materials and Methods).

\begin{tabular}{lllcc}
\hline Cell line & Treatment & & Cytolysis $(\%)$ & $p$-Value \\
\hline MCF-7 & Control & & $26.1 \pm 1.4^{\mathrm{a}}$ & \\
& Iron $(\mu \mathrm{M})$ & 50 & $22.2 \pm 1.5$ & $\mathrm{NS}$ \\
& & 200 & $20.2 \pm 1.9$ & $<0.05$ \\
& & 400 & $18.9 \pm 1.3$ & $<0.05$ \\
& DFOM $(\mu \mathrm{M})$ & 2.5 & $29.0 \pm 3.0$ & $\mathrm{NS}$ \\
& & 10 & $36.1 \pm 1.4$ & $<0.01$ \\
MDA-MB-231 & 40 & $33.9 \pm 3.7$ & $<0.05$ \\
& & & $18.3 \pm 2.1$ & \\
& Iron $(\mu \mathrm{M})$ & 50 & $15.6 \pm 1.8$ & $\mathrm{NS}$ \\
& & 200 & $13.5 \pm 1.5$ & $<0.05$ \\
& & 400 & $12.1 \pm 2.2$ & $<0.05$ \\
& DFOM $(\mu \mathrm{M})$ & 2.5 & $20.5 \pm 1.5$ & $\mathrm{NS}$ \\
& & 10 & $24.6 \pm 3.1$ & $<0.05$ \\
& & 40 & $26.8 \pm 2.3$ & $<0.01$ \\
\hline
\end{tabular}

aData are the mean \pm standard deviation of three replicates. NS: Not significant, compared to the medium control, $p>0.05$ by paired $t$-test.

apoptosis-inducing ligand (TRAIL) on NK cells, resulting in caspase-dependent apoptosis. Cytotoxic factors, contained in the granules and released from NK cells after interaction with the target cells through mutual surface 


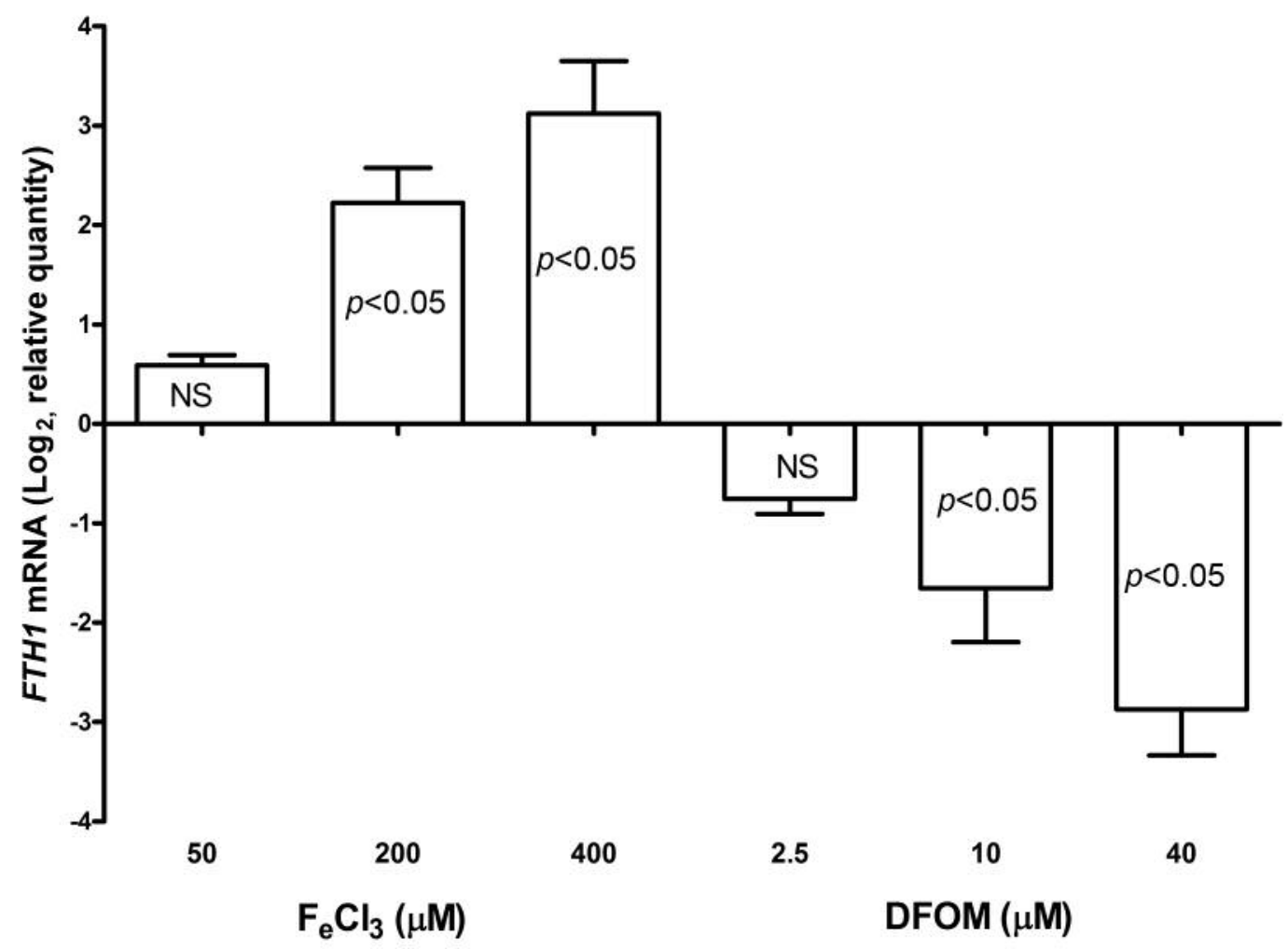

Figure 2. Iron up-regulates gene expression of ferritin heavy chain (FTH1); conversely, iron chelator deferoxamine (DFOM) inhibits FTH1 mRNA expression of MCF-7 cells during 4 h of incubation. NS: Not significant, compared to the control, $p>0.05$ by paired t-test (details are given in the Materials and Methods).

receptors, are able to induce both membrane and DNA damage in the target cells $(28,29)$. The function of NK cells, as well as their maturation and differentiation, are regulated by various stimuli, including IL2. In the present study, the cell line used, NK-92MI, is an NK cell line derived from the parent NK-92 cell line by transfection with human IL2 cDNA and therefore itself secretes IL2 (26). Great amount of research has shown that IL2stimulated $\mathrm{NK}$ cell tumoricidal activity correlates with increased NO production determined by measuring nitrite level in serum or culture media (30-33). NO can induce apoptosis and suppress tumor cell growth through depletion of intracellular iron in tumor cells. This effect of nitric oxide is similar to iron chelation by DFOM (34). In the current experiments, levels of $\mathrm{NO}$ are significantly increased when NK-92MI cells and MCF-7 or MDA-MB231 cells are co-cultured for 4 hours (Table I). The increase in NO can rapidly deplete intracellular iron and induce apoptosis of breast cancer cells. Thus iron depletion by NO is one mechanism of $\mathrm{NK}$ cell cytolysis. NO not only suppresses target cells but also protects NK cells themselves from activation-induced cells death and maintains their lytic capacity (35). Figure 1 shows that iron supplementation can significantly mitigate the cytotoxicity of NO, when released from the NO donor SNAP, in breast cancer cells. These results agree with a previous report by Feger et al. (34). We also found that addition of iron to cocultured NK-92MI cells and MCF-7 or MDA-MB-231 cells significantly inhibited the cytolysis of MCF-7 or MDAMB-231 cells by NK cells (Table III). However, iron and the iron chelator DFOM did not change the level of NO in the medium (Table II). Thus, iron partially suppressed cytolysis by NK-92MI cells by abrogating NO-induced iron depletion of MCF-7 and MDA-MB-231 cells.

Moreover, the availability of a high iron pool increases ferritin synthesis and, conversely, a low intracellular iron pool reduces ferritin synthesis by a post-transcriptional mechanism. This process is mediated by an interaction between RNA-binding proteins and a region in the 5, untranslated region of ferritin $\mathrm{H}$ and $\mathrm{L}$ chain mRNA termed the iron-responsive element $(36,37)$. Real time qPCR shows the addition of iron increases mRNA of FTHI in MCF-7 and MDA-MB-231 cells (Figures 2 and 3). Ferritin plays a role in immune suppression of NK cells. 


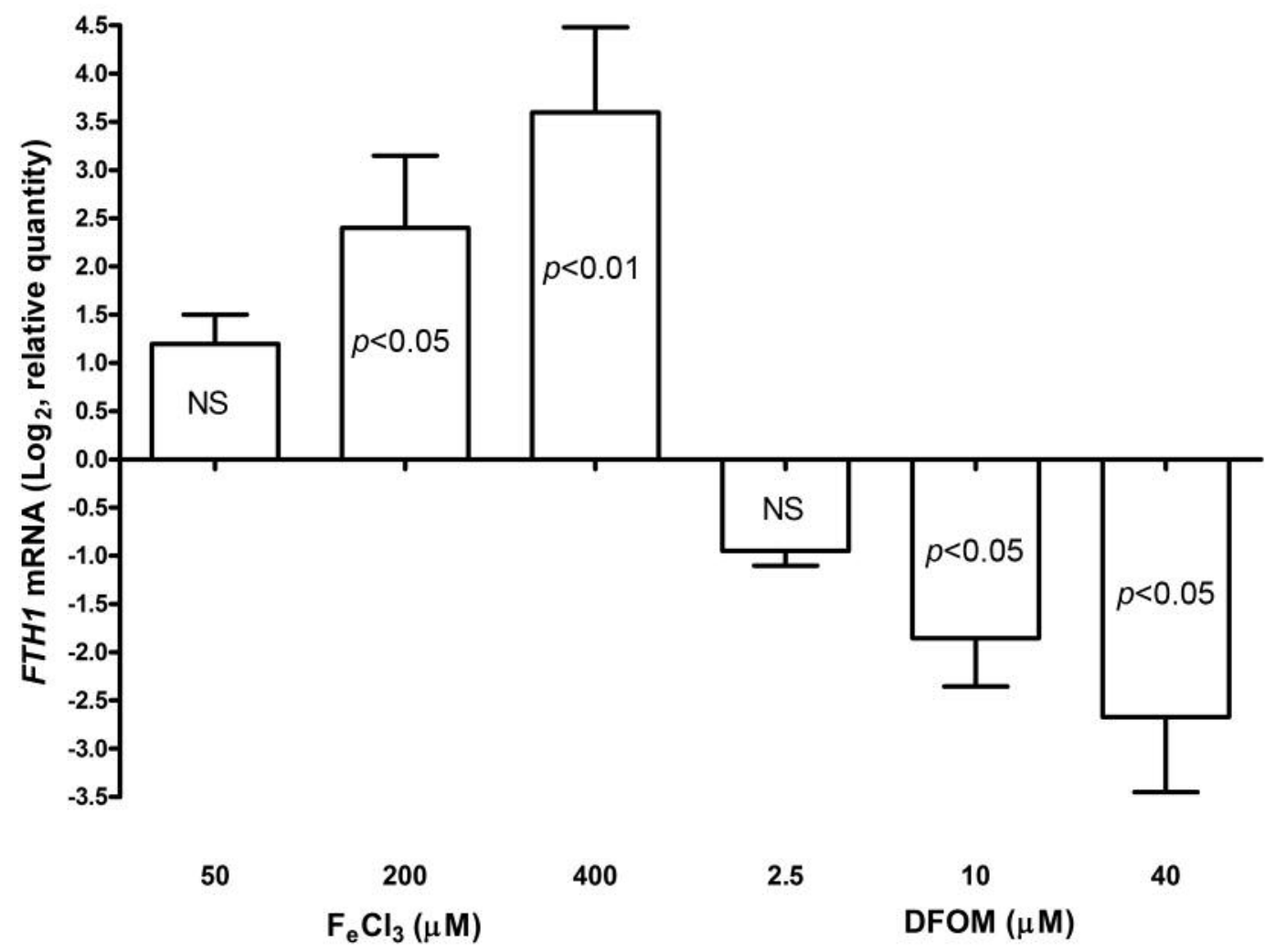

Figure 3. Iron up-regulates gene expression of ferritin heavy chain (FTH1); conversely, iron chelator deferoxamine (DFOM) inhibits FTH1 mRNA expression of MDA-MB-231 cells during $4 \mathrm{~h}$ of incubation. NS: Not significant, compared to the control, $p>0.05$ by paired t-test (details are given in the Materials and Methods section).

NK cells also release pro-inflammatory cytokines such as $\mathrm{TNF} \alpha$ to control tumor and virus-infected cells. In this study, we found that TNF $\alpha$ significantly increased during NK cells lysizing MCF-7 and MDA-MB-231 cells. TNF $\alpha$ was produced by NK-92MI cells and was undetectable in MCF-7 and MDA-MB-231 cells (Table I). TNF $\alpha$ binds to cell surface TNF $\alpha$ receptor and then activates both cell-survival and celldeath mechanisms simultaneously. Activation of NF-kBdependent genes regulates the survival and proliferative effects of TNF, whereas activation of caspases and induction of reactive oxygen intermediates, ceramide, phospholipases and serine proteases, regulates the apoptotic effects $(38,39)$. Reactive oxygen species (ROS) produced by TNF $\alpha$ have an important function in cell death by activating c-Jun $\mathrm{N}$ terminal kinase (JNK). However, the exact mechanism of mitochondrial ROS production, after TNF $\alpha$ stimulation, is not clearly understood. ROS modulator 1 is a molecular bridge between TNF $\alpha$ signaling and the mitochondria for ROS production that triggers $\mathrm{TNF} \alpha$-mediated apoptosis (38). Nuclear factor-kappa B (NF-kB) transcription factor antagonizes apoptosis induced by TNF $\alpha$. NF-kB inhibits JNK activation and also up-regulates FTH1 which suppresses ROS accumulation through the mechanism of iron sequestration. The suppression of ROS accumulation consequently inhibits JNK signaling and apoptosis (40). These data support that upregulation of ferritin protects cells from ROS and TNF $\alpha$ induced apoptosis. Down-regulation of ferritin may increase $\mathrm{TNF} \alpha$-induced apoptosis. We previously found that antisense oligonucleotides inhibiting the expression of FTH1 mRNA synergistically increased the cytotoxicity of recombinant TNF $\alpha$ to MCF-7 cells (41). It has been shown that DFOM depletes iron including free iron and bound-iron in ferritin and hemeprotein, and reduces the level of ferritin including $\mathrm{H}$ and L chains (42-44). Real-time qPCR showed that iron chelator DFOM reduced FTH1 mRNA levels in MCF-7 and MDA-MB-231 cells (Figures 2 and 3).

In the present study, addition of iron into the cell culture medium increased the intracellular iron and ferritin of breast cancer cells. Increased iron in cells and the medium neutralized NO-induced cancer cytolysis by NK cells. Elevated ferritin can protect breast cancer cells from TNF $\alpha$-induced cytotoxicity by NK cells. On the other hand, the iron chelator DFOM can tightly bind to iron in cells and culture medium, and down-regulate expression of FTH1. 
Thus, DFOM reduces the antiapoptotic activity of iron and ferritin during the interaction of NK cells with targets such as MCF-7 and MDA-MB-231 cells. These results are very important for clinical practice as patients with chronic infectious diseases, such as chronic hepatitis and cancer, often have increased levels of iron and ferritin, that may impair the patient's immune surveillance (45-48). Manipulation of iron and ferritin by nutrition and iron chelation may improve the anti-infectious and antitumor function of the immune system.

\section{Conflicts of Interest}

No conflicting financial interest exists.

\section{Acknowledgements}

This research was supported by funds from The Sallie Astor Burdine and Delta State University Foundations, Baton Rouge, Louisiana.

\section{References}

1 Thelander L, Graslund A and Thelander M: Continual presence of oxygen and iron required for mammalian ribonucleotide reductase: possible regulation mechanism. Biochem. Biophys Res Commun 110: 859-865,1983.

2 Thelander M, A. Graslund A and Thelander L: Subunit M12 of mammalian ribonucleotide reductase. J Bio Chem 250: 2737 2734,1985 .

3 Elford HL, Freese M, Passamani E and Morris HP: Ribonucleotide reductase and cell proliferation. Variations of ribonucleotide reductase activity with tumor growth rate in a series of rat hepatomas. J Biol Chem 245: 5228-5233,1970.

4 Heath JL, Weiss JM, Lavau CP and Wechsler DS: Iron deprivation in cancer - potential therapeutic implications. Nutrients 5: 2836-2859, 2013.

5 Jiang XP, Elliott RL and Head JF: Manipulation of iron transporation genes results in the suppression of human and mouse mammary adenocarcinomas. Anticancer Res 30: 759-766, 2010.

6 Levi S, Luzzago A, Cesareni G, Cozzi A, Franceschinelli F, Albertini A and Arosio P: Mechanism of ferritin iron uptake: activity of the H-chain and deletion mapping of the ferro-oxidase site. J Biol Chem 263: 18086-18092, 1988.

7 Green DA, Antholine WE, Wong SJ, Richardson DR and Chitambar CR: Inhibition of malignant cell growth by 311 , a novel iron chelator of the pyridoxal isonicotinoyl hydrazone class: Effect on the $\mathrm{r} 2$ subunit of ribonucleotide reductase. Clin Cancer Res 7: 3574-3579, 2001.

8 Oexle $\mathrm{H}$, Gnaiger $\mathrm{E}$ and Weiss G: Iron-dependent changes in cellular energy metabolism: Influence on citric acid cycle and oxidative phosphorylation. Biochim Biophys Acta 1413: 99-107, 1999.

9 King A, Selak MA and Gottlieb E: Succinate dehydrogenase and fumarate hydratase: Linking mitochondrial dysfunction and cancer. Oncogene 25: 4675-4682, 2006.

10 Blatt J and Stitely S: Antineuroblastoma activity of desferoxamine in human cell lines. Cancer Res 47: 1749-1750, 1987.
11 Kalinowski DS and Richardson DR: The evolution of iron chelators for the treatment of iron overload disease and cancer. Pharmacol Rev 57: 547-583, 2005.

12 Wang F, Elliott RL and Head JF: inhibitory effect of deferoxamine mesylate and low iron diet on the $13762 \mathrm{NF}$ rat mammary adenocarcinoma. Anticaner Res 19: 445-450, 1999.

13 Jiang XP, Wang F, Yang DC, Elliott RL and Head JF: Induction of apoptosis by iron depletion in the human breast cancer MCF7 cell line and $13762 \mathrm{NF}$ rat mammary adenocarcinoma in vivo. Anticancer Res 22: 2685-2692, 2002.

14 Cherayil BJ: Iron and immunity: immunological consequences of iron deficiency and overload. Arch Immunol Ther Exp (Warsz) 58: 407-415, 2010.

15 Oppenheimer SJ: Iron and its relation to immunity and infectious disease. J Nutr 131: 616S-635S, 2001.

16 Murray MJ, Murray AB and Murray MB: The adverse effect of iron repletion on the course of certain infections. Br Med J 2: 1113-1115, 1978.

17 Sazawal S, Black RE and Ramsan M: Effects of routine prophylactic supplementation with iron and folic acid on admission to hospital and mortality in preschool children in a high malaria transmission setting: community-based, randomised, placebo-controlled trial. Lancet 367: 133-143, 2006.

18 Gangaidzo IT, Moyo VM and Mvundura E: Association of pulmonary tuberculosis with increased dietary iron. J Infect Dis 184: 936-939, 2001.

19 Magnus SA, Hambleton IR and Moosdeen F: Recurrent infections in homozygous sickle cell disease. Arch Dis Child 80: 537-541, 1999.

20 Moyo VM, Gangaidzo IT and Gordeuk VR: Tuberculosis and iron overload in Africa: a review. Cent Afr J Med 43: 334-339, 1997.

21 Barton JC, Wiener HW, Acton RT and Go RC: Total blood lymphocyte counts in hemochromatosis probands with HFE C282Y homozygosity: relationship to severity of iron overload and HLA-A and -B alleles and haplotypes. BMC Blood Disord 5: 5-10, 2005.

22 Macedo MF, Porto G, Costa M, Vieira CP, Rocha B and Cruz E: Low numbers of $\mathrm{CD}^{+} \mathrm{T}$ lymphocytes in hereditary hemochromatosis are explained by a decrease of the most mature CD8+ effector memory T cells. Clin Exp Immunol 159: 363-371, 2010.

23 Melo RA, Garcia AB, Viana SR and Falcao RP: Lymphocyte subsets in experimental hemochromatosis. Acta Haematol 98: 72-75, 1997.

24 Mencacci A, Cenci E and Boelaert JR: Iron overload alters innate and $\mathrm{T}$ helper cell responses to Candida albicans in mice. J.Infect Dis 175: 1467-1476, 1997.

25 Pham CG, Bubici C, Zazzeroni F, Papa S, Jones J, Alvarez K, Jayawardena S, De Smaele E, Cong R, Beaumont C, Torti FM, Torti SV and Franzoso G: Ferritin heavy chain upregulation by NF-kappaB inhibits TNFalpha-induced apoptosis by suppressing reactive oxygen species. Cell 119: 529-542, 2004.

26 Tam YK, Maki G, Miyagawa B, Hennemann B, Tonn T and Klingemann HG: Characterization of genetically altered, interleukin 2-independent natural killer cell lines suitable for adoptive cellular immunotherapy. Hum Gene Ther 10: 13591373, 1999.

27 Anand Kumar P and Das SK: A colorimetric assay to evaluate the cytotoxic activity of the intestinal intraepithelial lymphocytes of chickens. Vet Res Commun 20: 513-518,1996. 
28 Mandal A and Viswanathan C: Natural killer cells: in health and disease. Hematol Oncol Stem Cell Ther 8: 47-55, 2015.

29 Zamai L, Ponti C, Mirando P, Gobbi G, Papa S, Galeotti L, Cocco L and Vitale M: NK cells and Cancer. J Immunol 178: 4011-4016, 2007.

30 Cifone MG, Ulisse S and Santoni A: Natural killer cells and nitric oxide. Int Immunopharmacol 1: 1513-1524, 2001.

31 Clfone MG, D'Alo S, Parroni R, Millimaggi D, Biordi L, Martinotti S, and Santoni A: Interleukin-2-activated rat natural killer cells express inducible nitric oxide synthase that contributes to cytotoxic function and interferon-r production. Blood 11: 3876-3884, 1999.

32 Yim CY, McGrefor JR, Kwon OD, Bastian NR, Rees M, Mori M, Hibbs JB and Samlow WE: Nitric oxide synthesis conbributes to IL2-induced antitumor responses against intraperitoneal Meth A tumor. J Immunol 155: 4382-4390, 1995.

33 Orucevuic A and Lala PK: Effects of $\mathrm{N}(\mathrm{G})$-nitro-L-arginine methyl ester, an inhibitor of nitric oxide synthesis, on IL2induced LAK cell generation in vivo and in vitro in healthy and tumor-bearing mice. Cell Immunol 169: 125-132,1996.

34 Feger F, Ferry-Dumazet H, Matsuda MM, Bordenave J, Dupouy M, Nussler AK, Arock M, Devevey L, Nafziger J, Guillosson JJ, Reiffers $\mathbf{J}$ and Mossalayi MD: Role of iron in tumor cell protection from the pro-apoptotic effect of nitric oxide. Cancer Res 31: 5289-5294, 2001.

35 Furuke K, Burd PR, Horvath-Arcidiacono JA, Hori K, Mostowski $\mathrm{H}$ and Bloom ET: Human NK cells express endothelial nitric oxide synthase, and nitric oxide protects them from activation-induced cell death by regulating expression of TNFo. J Immunol 163: 1473-1480, 1999.

36 Rogers $\mathrm{J}$ and Munro H: Translation of ferritin light and heavy subunit mRNAs is regulated by intracellular chelatable iron levels in rat hepatoma cells. Proc Natl Acad Sci USA 84: 22772281, 1987.

37 Zahringer J, Baliga BS and Munro HN: Novel mechanism for translational control in regulation of ferritin synthesis by iron. Proc Natl Acad Sci USA 73: 857-861, 1976.

38 Rath PC and Aggarwal BB: TNF-induced signaling in apoptosis. J Clin Immunol 19: 350-364, 1999.
39 Kim JJ, Lee SB, Park JK and Yoo YD: TNF $\alpha$-induced ROS production triggering apoptosis is directly linked to Romo1 and Bcl-XL. Cell Death Differ 17: 1420-1434, 2010.

40 Kucharczak J, Simmons MJ, Fan Y and Gelinas C: To be, or not to be: NF-kB is the answer - role of Rel/NF-kB in the regulation of apoptosis. Oncogene 22: 8961-8982, 2003.

41 Elliott RL and Head JF: Cancer: Tumor Iron Metabolism, Mitochondrial Dysfunction and Tumor Immunosuppression; "A Tight Partnership-Was Warburg Correct?" J Cancer Ther 3: 278-311, 2012.

42 Keberle H: The biochemistry of desferrioxamine and its relation to iron metabolism. Ann NY Acad Sci 119: 758-775, 1964.

43 Torti FM and Torti SV: Regulation of ferritin genes and protein. Blood 99: 3505-3516, 2002.

44 Heath JL, Weiss JM, Lavau CP and Wechsler DS: Iron deprivation in cancer--potential therapeutic implications. Nutrients 5: 2836-2859, 2013.

45 Shi HB, Li XD, Jiang JT, Zhao WQ, Ji M and Wu CP: Serum ferritin is elevated in advanced non-small cell lung cancer patients and is associated with efficacy of platinum-based chemotherapy. J Cancer Res Ther 10: 681-685, 2014.

46 Patil PS, Mohandas KM, Bhatia SJ and Mehta SA: Serum ferritin and the risk of hepatocellular carcinoma in chronic liver disease of viral etiology: a case-control study. Indian $\mathbf{J}$ Gastroenterol 33: 12-18, 2014.

47 Zhang XZ, Su AL, Hu MQ, Zhang XQ and Xu YL: Elevated serum ferritin levels in patients with hematologic malignancies. Asian Pac J Cancer Prev 15: 6099-6101, 2014.

48 Ochiai T, Nishimura K, Watanabe T, Kitajima M, Nakatani A, Inou $\mathrm{T}$ and Shibata $\mathrm{H}$ : Serum iron levels as a new biomarker in chemotherapy with leucovorin and fluorouracil plus oxaliplatin or leucovorin and fluorouracil plus irinotecan, with or without molecularly-targeted drugs. Mol Clin Oncol 1: 805-810, 2013.

Received March 14, 2017

Revised April 9, 2017

Accepted April 12, 2017 